Годишњак Филозофског факултета у Новом Саду, Књига ХХХVII (2012)

Горана С. Раичевић, Радослав Љ. Ераковић

UDK 821.163.41.09-3:27(497.11) Филозофски факултет Универзитета у Новом Саду Оригиналан научни рад gorana.raicevic@gmail.com, rasha@ff.uns.ac.rs

\title{
ПОРТРЕТИ КАРЛОВАЧКИХ МИТРОПОЛИТА У ДЕЛИМА СРПСКИХ ПИСАЦА ${ }^{1}$
}

У овом раду представљени су резултати упоредног истраживања стваралачког опуса двојице писаца, чија дела припадају вредносном врху српске књижевности 19. и 20. века (Јаков Игњатовић, Вељко Петровић). Посебна пажња посвећена је ликовима карловачких митрополита у њиховим прозним остварењима, односно чињеници да њихови портрети нису обликовани у складу са подацима које је могуће пронаћи у званичним историографским и биографским изворима. Чињеница да су наведени писци велику пажьу посвећивали приватној сфери живота својих (анти)јунака, омогућила је ауторима овог рада да закључе како свака литерарна конструкција, упркос упадљивој субјективности приповедача, може пружити допринос вернијој реконструкцији националне прошлости.

Кључне речи: Карловачка митрополија, Јаков Игњатовић, Јосиф Рајачић, Стефан Стратимировић, Вељко Петровић, Герман Анђелић, Георгије Бранковић, мемоари, приповетке

Континуиран утицај парадигматских обележја епохе коју означавамо као постмодерну, довео је до поступног преображаја традиционалног статуса историје и књижевности, постављајући их ближе једну другој. Са равни „науке“, историја се све више премешта на раван „приче“, чиме се отварају и могућности за ревизију одређених општеприхваћених судова, уз посебан осврт на „официјелна“ виђења националне прошлости. Тако и дела књижевности почињу да се посматрају као релевантни историјски извори, не много субјективнији од историографије, која је много пута до сада (раз)открила своју рањивост (нарочито кад су у питању врло приватни, односно лични

1 Рад је реализован у оквиру пројекта “Фрушка гора у књижевности”, који финансира Покрајински секретаријат за науку и технолошки развој (руководилац пројекта: проф. др Љиљана Пешикан Љуштановић). 
интереси „компетентних“ тумача кључних историјских догађаја). У овом раду покушаћемо да расветлимо узроке „специфичног“ односа двојице српских књижевника из „војвођанске“ средине - Јакова Игњатовића и Вељка Петровића - према појединим поглаварима Карловачке митрополије, установе која је од 1708. године (Грујић 1929: 194) представљала централну институцију Срба у Хабзбуршкој монархији. Историја народа који се на просторе Јужне Угарске насељавао бежећи од Турака, чак и на основу само ова два примера, открива се као историја оптерећена трагичним подељеностима, подједнако погубним за животе појединаца колико и за политички и друштвени живот српског националног ентитета у средњоевропској монархији. Бреме те трагичности поднели су и о њој писали српски писци Јаков Игњатовић (1822-1889) и Вељко Петровић (1884-1967), осветљавајући при том и ликове поглавара Карловачке митрополије - непосредног носиоца и заступника народно-црквено-школске аутономије војвођанских Срба. Управо о портретима карловачких митрополита, односно патријарха, из пера Јаше Игњатовића и Вељка Петровића, осликаним у контексту приче о ширим друштвеним противречностима и трагичним конфликтима на овим просторима, говорићемо у овом раду.

\section{$* * *$}

Делови обимних мемоарских записа Јакова Игњатовића први пут су објављени у новосадском Недељном листу, књижевном и политичком часопису који је основао и уређивао управо сентандрејски романсијер. Одломци из мемоара Ј. Игњатовића (првобитни наслов) излазили су у наставцима од 1879. до 1881. године. Мада је наведено дело настало у периоду када је аутор био на врхунцу стваралачких моћи, прве генерације читалаца показале су велику уздржаност према успоменама популарног писца. Разлог због чега је веома тешко издвојити трагове позитивне рецепције, барем у тренутку када су Мемоари представљали део актуелне литерарне продукције, требало би потражити у тешким оптужбама савременика да је главни уредник Недељног листа био плаћеник мађарске владе и шпијун министра Калмана Тисе (18301902). Упркос жестини (политички мотивисаних) напада на остракизованог аутора - нарочито крајем седамдесетих и током осамдесетих година 19. века - 
требало би потпуно занемарити сва ванлитерарна исходишта некадашње негативне рецепције Мемоара. С обзиром на чињеницу да је био сведок и (невољни) учесник драматичних догађаја из 1848. године, сасвим је разумљиво што је Јаков Игњатовић у својим мемоарским записима велику пажњу посветио револуционарним превирањима у тадашњој Аустрији. Међутим, морамо нагласити да је (за савременог читаоца прилично заморно) фактографско бележење и тумачење сваког детаља шестомесечног боравка у Сремским Карловцима и Срему, било мотивисано ауторовом интимном потребом да оправда своје поступке, који су му донели велике невоље током живота. Наиме, Јаков Игњатовић је први пут стигматизован као мађарон и лош Србин већ током Мајске скупштине. Млади и полетни сентандрејски адвокат, представник српске заједнице из Чобанца (околина Сентандреје), превише отворено је изражавао своје дубоко уверење да су прави непријатељи Срба дволични Хабзбурговци, а не Мађари. Мада је време показало у којој мери су његова здраворазумска промишљања била тачна, сенка наводног мађаронства следила је Јакова Игњатовића све до смрти. Упркос томе што је пажљиво описао велики број кључних догађаја из Буне, попут војних сукоба са Мађарима и (по судбину народа не мање опасних) политичких преговора са Бечом, само једна личност је упорно привлачила пажњу аутора, митрополит карловачки и патријарх српски, Јосиф Рајачић (1785-1861). Упоредна анализа кључних поглавља Мемоара, упућује на закључак да је животопис црквеног великодостојника и политичког вође Срба у Аустрији, поступно прерастао у ауторову опсесивну тему. Односи Јакова Игњатовића и патријарха Рајачића били су обележени низом успона и падова који су, барем према тумачењу резигнираног и великим животним искуством обогаћеног приповедача, превасходно били проузроковани способношћу аутократски настројеног архипастира да манипулише судбинама људи из сопственог окружења. Веома је лако уочити да су најзначајнији искази аутора утемељени на уверавању потенцијалних читалаца како ће улога Јосифа Рајачића у догађајима из 1848. и 1849. године бити сагледана из перспективе дистанцираног и објективног сведока, који се ослања искључиво на историографски валидне податке (Игњатовић 1988: 355). Међутим, портрет некадашњег политичког и духовног вође српског народа је - упркос „чврстим“ обећањима аутора Мемоара - испао објективан колико и описивање владавине 
Милоша Обреновића (1780-1860) у мемоарским исповестима Нићифора Нинковића (Нинковић 1988). Претпоставка о присуству недовољно проучене тематске линије додира, проистекла је из анализе биографских података који указују да су двојица аутора, готово у подједнакој мери, били принуђени да трпе хирове свемоћних властодржаца. Мада Јаков Игњатовић никада није био изложен оријентално маштовитим облицима физичког и менталног малтретирања попут злосрећног књажевог берберина, чију је послушност кнез Милош обезбеђивао батинама и претњама да ће му жена бити јавно силована (Нинковић 1988: 198-200), аутор Мемоара је имао више него довољно разлога да буде незадовољан поступцима српског патријарха. Подсетићемо само на чињеницу да је његово хапшење и извођење пред преки суд у лето 1848. било изведено уз благослов (sic!) Јосифа Рајачића, који је веровао да ће млади и својеглави Сентандрејац бити расположенији за сарадњу након боравка у магистратском затвору. Као што се могло очекивати, мучно затворско „тиховање“ је убрзо приморало младог Јакова Игњатовића да прихвати своју улогу у револуционарним догађајима, односно место уредника службеног листа нове власти, карловачког Весника. Међутим, нико није могао предвидети чињеницу да ће будућем књижевнику тиме бити пружена прилика да сазна много тога о (српској јавности непознатим) навикама моћног патријарха. Захваљујући приповедачком таленту Јакова Игњатовића, пикантни детаљи из свакодневног живота Јосифа Рајачића данас поседују много већи рецепцијски потенцијал од педантних описа рада новоформираног чиновничког апарата Српске Војводине. Као потврду нашег запажања, одлучили смо да издвојимо одређене фрагменте Мемоара, који откривају опскурно наличје званичне биографије једног од вођа Буне. Због тога што му је специфична природа наведених послова омогућавала да борави у најближем окружењу црквеног великодостојника, аутор је веома брзо сазнао за коцкарску страст свог претпостављеног. Уместо да се непрекидно моли за спас и победу бораца који су крварили у околини Сентомаша и Вршца, или чак узме пушку у руке попут Проте Матије Ненадовића (1777-1854), блазирани миљеник Хабзбурговаца и бечке реакције много више је волео да у слободно време игра карте са својим снисходљивим чиновницима (Игњатовић 1988: 378-379). Међутим, Рајачићево јавно исказивање презриво-подсмешљивог односа према славном претходнику, карловачком митрополиту Стефану 
Стратимировићу (1757-1836), оправдава у већој мери ауторово континуирано оспоравање патријарховог моралног и етичког кредибилитета (Игњатовић 1988: 381). Наиме, Јосиф Рајачић је са великим задовољством препричавао како је епископско достојанство добио захваљујући царској наредби, противно вољи митрополита Стратимировића који га је, за разлику од већине учесника Мајске скупштине, веома брзо прозрео. Морамо нагласити да је аутор уложио велики труд како би потенцијалним читаоцима указао на (оправдане) разлоге Стратимировићеве нетрпељивости, уз посебан осврт на посредна сведочанства о Рајачићевом неприхватљиво млаком отпору према покушајима унијаћења на територији Војне крајине. Специфична функција митрополита Стратимировића у структури Мемоара, наговештава присуство још једне релевантне линије додира са успоменама књажевог берберина. Описујући тиранију Милоша Обреновића, Нићифор Нинковић непрестано повлачи паралеле са владавином Карађорђа Петровића (1752-1817). Без обзира на преку нарав вође Првог устанка, сва поређења двојице владара у Жизниописанију изведена су тако да потврде моралну и етичку супериорност Црног Ђорђа (Нинковић 1988: 13-14). Трагове идентичног компаративног поступка можемо запазити и у делу Јакова Игњатовића. Да будемо прецизни, аутор подсећа на много пута потврђено родољубље Стефана Стратимировића који је, без обзира на противљење Беча, активно помагао Карађорђеве устанике (Игњатовић 1988: 375-376 и 382). Истовремено, није пропуштена прилика да се нагласи како је љубав Јосифа Рајачића према сопственом народу увек била подређена његовим личним амбицијама и интересима Хабзбурговаца (Игњатовић 1988: 374). Иако су мане и (наводно многобројни) пороци Јосифа Рајачића помно побројани, ниједан од пишчевих коментара не упућује на право исходиште нескривене нетрпељивости према карловачком патријарху. Наиме, десет година након исторических збитија описаних у Мемоарима, одиграли су се догађаји који заслужују да буду означени као својеврсна кулминациона тачка (вишегодишњег) сукоба између плаховитог Сентандрејца и политичног калуђера (Игњатовић 1988: 381). Упркос некадашњим несугласицама, Јаков Игњатовић је средином августа 1858. постао Рајачићев секретар. Убрзо након што је некадашњи „издајник српског рода“ преузео угледан положај у Сремским Карловцима, Митрополијска штампарија објављује прву свеску његовог историјског романа Ђурађ Бранковић. Међутим, 
идила није дуго потрајала. Због новчаних проблема и све израженијих приватних размирица са наводно ауторитарним патријархом, српски романописац демонстративно напушта место секретара почетком јесени наредне године. Његовим понашањем згранути „послодавац“ није му остао дужан. Праштању несклони Јосиф Рајачић спречава даљу штампу и дистрибуцију Ђурађа Бранковића. Њихов лични и политички сукоб је, нажалост, потрајао све до патријарховесмрти 1861.године.Посматраносастановиштакњижевноисторијске релевантности, неконвенционални приступ избору мемоарске грађе, односно доминантан статус епизода из сфере приватног, пружа нам драгоцен увид у свакодневни живот личности чије су (политичке) одлуке несумњиво обележиле епоху којој је мемоариста припадао. Уклањањем пригодне церемонијалне укочености (која их је трансформисала у мештровићевски смркнуте каријатиде српске историје) Јаков Игњатовић је представио своје угледне савременике и (не)пријатеље на врло упечатљив начин, нехотично стварајући нацрт за (рецепцијски веома привлачну) историју приватног живота карловачких архипастира.

Чињеница да је написао свега две приповетке чија је радња смештена у Сремске Карловце, као и неколицину са тематиком манастирског живота у Фрушкој гори, не говори нимало о значају који је Вељко Петровић придавао овом „српском Сиону“ и његовој малој престоној вароши. Карловци су за овог писца дубоко укорењеног у традицију „војвођанског“ српства били „не центрум, не пупак света, већ цео свет“ (Петровић, В. 1964а: 211). Дубоко заокупљен историјом оног дела српског народа којем је и сам припадао, а који се на просторе Јужне Угарске масовно досељавао пред најездом Турака од краја 17. века, и који је у Хабзбуршкој монархији покушавао да организује свој живот на начелима испрва црквено-школске а затим и политичке аутономије, Вељко Петровић је можда осећао да је овој проблематици примеренија опсежнија књижевна форма од приповетке - форма романа који, међутим, никада није стигао да напише. Прва од две поменуте приче настала је између два светска рата и носи наслов: „Карловачки доживљај 1889. године“ (1935). Друга прича 
се први пут појавила у Летопису Матице српске тек 1962. године („Кога то Бимба опет оглашава“). Радња ове друге приповетке - која као и прва, има јасно назначене историјске координате - смештена је у исту годину, овај пут на сам њен почетак. Из писама које је Васи Стајићу писао непосредно после рата, пред његову смрт, види се да је писац ову тему стално носио у себи као врело инспирације, а писма упућена ондашњем уреднику Летописа Живану Милисавцу, у којима од својих пријатеља тражи историјску грађу о филоксери, Миши и Јаши, Застави и Бранику, патријарху Герману Анђелићу, сведоче о томе да је Вељка Петровића занимао управо овај период историје војвођанских Срба и да су његове амбиције изгледа ишле у правцу стварања циклуса приповедака, ако не и романа, који никада није успео да напише. Трагика „малих” људи, појединачних судбина описаних у овим приповеткама одвија се на фону шире трагичке позорнице, у години у којој се обележавало пет векова од Косовске битке. У приповеци објављеној између два рата, ламентујући над судбином и карактером народа којем „нема лека”, ректор карловачке богословије каже:

- Ето, летос смо држали тужну славу, парастос, петстогодишњицу Косовске битке, па...па... да л’ смо бар, у покој Лазареве и Милошеве душе, пружали братски једно другом руке? Брука и срамота за бруком и срамотом! Ми, овде, отерасмо свог црквеног поглавицу у гроб, Јаша заклао Мишу, па се народ подвојио, неће ни истом страном на улици да иде, ни у истој цркви богу да се моли, а Беч и Пешта и Стамбул ликују, с видовданског помена прве људе нам терају у тамницу, и то помоћу жбира наше крви...А, тамо, преко ... краљ гони од себе краљицу као слушкињу, отима јој сина, а партије се крве, праве хајдучке чете, док нас у Старој Србији требе Арбанаси као зверад!...Нема нама лека!...Нема нама лека!... (Петровић, В. 1964: 284)

Чињеница да је у овом одломку могуће открити анахронизме (Јаша Томић убио је Мишу Димитријевића тек крајем исте године, по новом календару 6. јануара 1890, док је краљ Милан протерао краљицу Наталију тек 1891, не говори о пишчевом непознавању историје, већ управо о чињеници да га је уметничка слобода навела да у једну годину концентрише догађаје што су српски народ и са ове и са оне стране Саве и Дунава довели до кобних подела, у којима није само он видео прави узрок њихове несреће. Чини се да 
је у том светлу посматрано, Вељко Петровић обликовао и властито виђење сукоба такозваних либерала окупљених око Светозара Милетића и Карловачке митрополије као носиоца конзервативних и клерикалних вредности. Онај црквени поглавица за којег се у одломку каже да га је његов народ отерао у гроб, јесте Герман Анђелић омражени „лажипатријарх“ који је, уместо да га изгласа народ, устоличен по налогу властодржаца из Беча и Пеште. Герман је заиста био умро 1888. године, не заслуживши чак ни конвенционални стил некролога - ,о мртвима све најлепше“. Из писама Вељкових, али и из сведочења Теодоре Петровић, види се да је наш писац био јако заинтересован за трагичну судбину патријарха чијем је погребу као петогодишњи дечак присуствовао у карловачкој Саборној цркви. (Петровић, Т. 1981: 416) О потресном и горком плачу Германовог брата Стевана, митровачког проте, писао је једном приликом Кости, Теодорином брату. Патријарха Германа (којег још назива и „Калуђерски Милетић“) приказао је кратко, прво по својој позицији коју је, опет на челу једне групе супротстављене другој, заузимао, а онда како га је запамтио у свом сећању. Ипак, у том односу има некакве благости, саучествовања у трагици, што увелико одудара од одијума јавности према омрзнутом патријарху који је трајао чини се све док га није прекрио вео заборава. А центар тих збивања, Анђелићевих и Милетићевих борби, били су, наравно, Карловци:

...Стога су се ту и водиле непомирљиве, очајне борбе између слободоумне Милетићеве интелигенције и народних маса, на једној страни, и између конзервативаца око „Калуђерског Милетића», несрећног и високо образованог патријарха Анђелића.

Тог Анђелића сам видео, као дете од четири године, али запамтио сам га, као да га сад гледам.

У летње подне нашао сам се с нашом Драгом мимо двора. На примамљиво тупи удар пале, зреле кајсије попео се на соклу од црвеног мрамора и ухвативши се гвоздене шипке, за копља дворске ограде, пожудно буљио у меки, наранџасти плод у трави. И онда се појавио поштапајући се, сасвим погрбљен, мален поп, са седом опуштеном брадом и с опуштеним златним ланцем. Нешто смо као говорили, на што се он, стењући, саже. Други неки млади, обријани, у свиленој мантији, подиже кајсију, пружи је старцу а старац мени. Кажу, још је нешто питао, рекао, али ја се сећам само 
слике, а не речи. После сам слушао, а из разних портрета и снимања се уверио: Анђелић је био стасит, динарски делија, орловског ока и носа, а, ето, неколико месеци пред смрт, једном детету се учинио омалена попица. Сломила га је свирепа борба с народом. Присуствовао сам и његову тужном погребу. Јахао сам на врату високог лепог матуранта Јефте Петровића. Густа маса је прекрилила цели трг испред Саборне цркве. Све је било немо, као скамењено, тако да се чуло појање из храма, кажу, и најпотресније и најлепше надгробно слово које се у нас икада чуло, трагично савлађивани басбаритон великог Анђелићевог такмаца, Теофана Живковића, плашкога владике: „Блажени, ниси био блажени»...(!)

У исте дане се свуд по карловачким домовима помињало: како се испуњава српска коб; у исти час кад се остаци измрцвареног „Калуђерског Милетића» спуштају у гроб, истинскоме Милетићу, вођи народа, „Риђем Демону», како га је називао покојни Герман с амвона, - помрачује се ум. Још једино што може, од јутра до мрака чита трагични текст Тацита. Али, да ли шта разуме од тога? (Петровић, В. 1964a: 214-215)

У другој приповетки о Карловцима из 1889. године, у чији наслов је, опет анахроно, смештено чувено звоно звано Бимба, које је по речима Теодоре Петровић на звоник Саборне цркве постављено тек 1907. године, за време чувеног митрополита Георгија Бранковића, окосницу приче чини анегдота о несрећној „карловачкој Софији», што се бацила у Дунав због несрећне љубави момка, који се закалуђерио уместо да се њоме ожени, и о којој је испевана и песма:

\footnotetext{
Карловачка Софија

у Дунав је скочила:

мртва куне те невере,

црне калуђере.
}

Иако је прави повод заправо погибија аустријског престолонаследника Рудолфа, чија је тајновита смрт била инспирација многих литерарних остварења, звоњава Бимбина за Софију оплакује њену несрећну љубав, а за српски народ његову трагичну судбину. У овој причи, међу несрећама српским, помиње се 
и „невера проте Ђорђа Бранковића”, потоњег митрополита Георгија, великог добротвора и Германовог наследника:

Сви, без разлике, несрећни Срби, одмах пошто дознаше кога Бимба оглашава, помислише на своје на српске поразе и бруке последњих година: на Милана и Наталију, на лудило Светозара Милетића, на неверу проте Ђорђа Бранковића, итд. (Петровић, В. 1964: 199)

У чему је била „невера“ проте Ђорђа Бранковића, потоњег патријарха Георгија, разјасниће нам Вељко Петровић у једној својој касној причи објављеној у Борби 1966. године и прештампаној у књизи То су они - то смо ми (1970), коју је после пишчеве смрти приредио Бошко Петровић. У приповеци „Скроман отац - моћан син“ писац нам даје неку врсту кратке биографије славног патријарха - од тренутка када је, уместо за свога оца - сенћанског пароха Тиму, од бачког владике Платона Атанацковића за себе измолио црвени појас. Посебно је интригантан онај део приче у којем је, поставши сомборски прота и удовац, Ђорђе осрамотио и у смрт отерао жену која се бринула о његовој деци, што га је и учинило рањивим и подложним уценама власти да, иако у души милетићевац, на народно-црквеном сабору гласа за Пешти и Бечу драгог Германа. Прича Вељкова, дакле, не говори толико о чувеном патријарху Георгију, мецени и добротвору којем Карловци, са својом Патријаршијом, Богословијом и богословским семинаром дугују свој данашњи изглед, већ о проти Ђорђу - човеку овоземаљске грешности из којег је онај други израстао. Портрет славног патријарха изграђен је сасвим у складу са опаском оца Тиме сломљеног изненадним увидом у макијавелистичку природу свога сина: „Ти ћеш, синко, или на вешалима свршити или ћеш далеко дотерати!“ (Петровић, B. 1970: 23)

Ставивши у уста једног од ликова карактеристичну узречицу (али без њеног оптимистичког другог дела ,...али ми нећемо пропасти“) једне историјске личности, проте Димитрија Руварца, ${ }^{2}$ Вељковог савременика и пријатеља, који је цео свој живот провео у донкихотовској борби са националним и историјским

2 О проти Руварцу и о овој његовој чувеној изреци пише и Дејан Медаковић у свом Ефемерису, слушајући о њему приче свог рођака Радивоја Врховца, директора Карловачке гимназије пред Други светски рат:,Нема нама спаса, али ми нећемо пропасти, тачно је то рекао наш рођак деда Мита Руварац...» (Медаковић 1995: 227) 
грешкама и промашајима свог народа, писац као да нас наводи на закључак да су догађаји из карловачке историје и у свести пишчевој били онај окидач који је постепено водио пропадању и опадању пре свега оног „уморног Српства“ у Војводини, али и оног у Србији, које су тако једнодушно видели и бележили писци наше модерне. Филоксера је уништавала винограде и у економску пропаст водила српски грађански слој фрушкогорског краја који се на вину и подигао, али много дубљу, много далекосежнију пропаст узроковали су људи, а да нису били ни туђини ни завојевачи. Дајући своје портрете два карловачка патријарха - Германа Анђелића и Георгија Бранковића - Вељко Петровић је показао да права историја није онако црно-бела како неки желе да је представе, и да у њој нема ни демона ни анђела, што пре свега говори о његовом осећању о општој и заједничкој одговорности за поделе српског народа у историји, без обзира на то које су то идеје одређивале ту поларизацију. Иако није као Јаша Игњатовић био непосредан сведок историје о којој је писао, Вељко Петровић је осећао њене последице, сасвим сигурно и после 1918, али и 1945. године - када је питање војвођанског српства, у већим државним заједницама јужних Словена наизглед било решено. Ипак - чак и ако се у Мемоарима Јаше Игњатовића може препознати тенденциозност заснована на жељи сочинитеља да себе представи у бољем светлу (што је уосталом и опште место мемоарске литературе) политички и друштвени догађаји преломљени кроз литерарну призму, чак и ако говоре о историјским догађајима из перспективе (огорченог) појединца, губе политичку димензију у корист оне општељудске, пружајући драгоцени допринос не само смиривању трагичних историјских острашћености, него и објективнијем виђењу (што је својеврстан парадокс!) суморних догађаја из националне прошлости.

\section{ЛИТЕРАТУРА}

Грујић, Радослав (1929). „Проблеми историје Карловачке Митрополије“. ГИДНС. ІІ/св. 2. 194-204.

Игњатовић, Јаков (1988). Мемоари (прир. Ж. Бошков). Београд: Нолит.

Медаковић, Дејан (1995). Ефемерис: хроника једне породице I, Београд: Београдски издавачко-графички завод. 
Михајловић, Борислав (1988). Портрети. Београд: Нолит.

Нинковић, Нићифор (1988). Жизниописанија моја (прир. Т. Поповић). Београд: Нолит.

Петровић, Вељко (1964). Изданци из опаљеног грма II (Сабрана дела Вељка Петровића књ. 3). Београд-Нови Сад: Просвета-Матица српска.

Петровић, Вељко (1964а). Разговору никад краја (Сабрана дела Вељка Петровића књ. 6). Београд-Нови Сад: Просвета-Матица српска.

Петровић, Вељко (1970). То су они, то смо ми (прир. Бошко Петровић). Нови Сад: Матица српска.

Петровић, Теодора (1981). Сећања. Нови Сад: Матица српска.

Gorana S. Raičević, Radoslav Lj. Eraković

THE PORTRAITS OF METROPOLITANS FROM KARLOVCI DIOCESE BY SERBIAN WRITERS OF $19^{\mathrm{TH}}$ AND $20^{\mathrm{TH}}$ CENTURY

\section{Summary}

The essay is the result of the comparative study on two prominent Serbian writers from $19^{\text {th }}$ and $20^{\text {th }}$ century: Jakov Ignjatović and Veljko Petrović. Particular attention is paid to the ways both of them have portrayed a few metropolitans of Karlovci diocese, offering pictures different from those presented by official history. The authors tend to believe that each literary construction written in the context of so-called private history (despite its subjective point of view) has to be considered as relevant for a more truthful historical reconstruction.

Key words: Karlovci diocese, Jakov Ignjatović, Josif Rajačić, Stefan Stratimirović, Veljko Petrović, German Andjelić, Georgije Branković, memoirs, short stories 